\title{
NOTAS SOBRE A MEDIAÇÃO ENTRE O ERUDITO E O POPULAR*
}

\author{
Pltnio Freire Gomes**
}

RESUMO: Através das reflexões pioneiras de Gramsci e Bakhtin, percebeu-se que as camadns subalternas também eram capazes de construir sua própria concepção de mundo. Mas a idéia de "cullura popular" já havia sido largamente utilizada antes deles. Criada em fins do século XVIII como parte da proposta estética do romantismo, ela ajuclou a funchar uma percepçâo dicotômica da sociedade que só agora começa a ser questionach. Hoje fica cacla vez mais clara a importância dos individuos que atuavam como mediadores entre o "erudito" e o "popular", estabelecendo pontos de contato ou reforçando suas zonas de atrito.

PALAVRAS-CHAVE: Cultura Popular, Século XVIII, Romantismo, Literatura e História, Visão de Mundo.

"As relaçóes dialógicas são um fenômeno quase universal, que penetra loda linguagem e todas as relações e manifestaçóes da vida humana, em suma, tudo o que tem sentido e importancia."

\section{Mikhail Bakhtin, Problemas da Poética de Dostoiévski.}

Atualmente parece inegável que o fascínio pela cultura popular vem se impondo de forma cada vez mais marcante ao debate historiográfico. Se as investigações sobre as mentalidades obtiveram tanto sucesso a partir dos anos 60 , hoje já é possível perceber que elas começam a dividir sua posiçăo de primazia com o crescente interesse pelo problema do descompasso cultural entre a elite e o povo. Mesmo porque, a proposta de buscar no passado as especificidades do modo de vida e do pensamento originado nos grupos

\footnotetext{
* O presente artigo é uma versăo ampliada da comunicação apresentada no XVI Simpósio Nacional da ANPUH, em julho de 1991, com o título de "Repensando os Intermediários Culturais". Agradeço a minha orientadora, Prof ${ }^{2}$. Dr ${ }^{a}$. Laura de Melto e Souza, pelas valiosas sugestóes que me foram oferecidas neste trabalho.

** Mestrando em História Social - Depto. Ue História - FFLCH-USP.
} 
GOMES, PIInio Freire. Notas sobre a mediação entre o erudito e o popular.

subalternos permitiria lançar um enfoque inteiramente novo sobre a eterna face oculta da história. Ou seja, aquele espaço nebuloso onde encontram-se mergulhados os homens excluídos pela documentação que legamos de seus opressores.

Entretanto, a idéia de que o povo elabora um universo cultural próprio - e, com frequéncia, oposto aos saberes confeccionados pela nata bem-pensante - não representa nenhuma novidade. Apesar de haver sofrido inúmeras alteraçōes, o conceito de "cultura popular" remonta a fins do século XVIII. E se esperamos que ele sobreviva aos condicionamentos da época na qual foi concebido, precisamos, desde logo, reconsiderar as suas implicaçóes mais profundas. Sendo assim, no presente artigo pretendo fazer um breve esboço do seu desenvolvimento histórico, tentando identificar as dificuldades trazidas por esta entusiástica (e, por que não dizer, apressada) reabilitação.

Porém, meu principal intuito será o de propor, como alternativa, um encaminhamento centrado na escorregadia figura dos "intermediários culturais". Refiro-me àquele conjunto de indivíduos particularmente refratários aos nossos sistemas classificatórios porque tendiam a construir seu pensamento através da miscigenação de influências tanto dos círculos populares, quanto dos eruditos. Embora esta singularidade pareça um obstáculo intransponível, penso ser precisamente por causa dela que devemos pesquisá-los.

Como procurarei demonstrar, o caráter ambíguo dos intermediários está nos colocando diante da possibilidade de edificar um outro tipo de conhecimento histórico. Eles são nosso maior ponto de contato com a dimensão altamente tensionada da realidade que chamarei aqui de "dialógica": um domínio no qual as mais diversas vozes ecoam para se combinarem ou se repelirem, sem que nunca cheguem a se anular inteiramente ${ }^{1}$. E, assim, talvez possamos năo apenas corrigir as insuficiências do já bem maduro conceito de cultura popular, como também apresentar um novo meio de abordagem aos trabalhos ligados à questão das mentalidades.

\section{A "Cultura Popular" de Herder a Bakhtin}

Com o esgotamento do classicismo, aliado à reação contra o pensamento iluminista, alguns homens letrados começaram a reconhecer o valor

Estou adaptando uma das muitas idéias seminais de Mikhail Bakhtin: "dialogicidade" 6 a categoria central do şeu Problemas da Poética de Dostoiévski. Trad, Rio de Janeiro, Ed. ForenseUniversitrária, 1981. 
estético de tradições que eram até então encaradas apenas como um fruto da miséria moral e intelectual da plebe. Em 1778, Johann Gottfried Herder publicava uma antologia de canções coletadas entre rústicos camponeses, ressaltando que elas ainda guardavam a mesma força expressiva da poética desenvolvida pelos hebreus e pelos gregos antigos. Colocava-se ali um marco fundamental: Herder foi o primeiro a falar em "cultura popular" - já a caracterizando como um conjunto de manifestações independentes e, de certa forma, contrapostas àquilo que ele chamou de "cultura erudita" ${ }^{2}$.

Esta nova perspectiva teve ampla repercussão na época, influenciando autores da estatura de Goethe e ajudando a formar as bases do estilo romântico. No início do século XIX, porém, os irmãos Grimm promoveriam outro avanço significativo. Além do cuidado em tornar mais sistemático o trabalho de recolhimento de dados, eles reforçaram o vínculo entre o povo e a riqueza literária das suas narrativas. Ao comentarem o problema da composição das lendas e contos infantis transmitidos em comunidades aldeãs, os Grimm introduziram a idéia extremamente inovadora da autoria coletiva: "o povo cria", afirmavam eles ${ }^{3}$.

Entretanto, o que os românticos entendiam pela palavra "povo" tem muito pouco a ver com a sua significação atual. Antes de mais nada, ela não se referia aos pobres e, menos ainda, ao perigoso proletariado que povoava os grandes centros urbanos. Aquela noção aludia, na verdade, a uma imagem idealizada do homem humilde, cujo principal protótipo era a figura do camponês ${ }^{4}$. Por outro lado, eles não estavam interessados nas manifestaçóes populares como um todo: o objetivo era salientar exclusivamente os elementos culturais que correspondessem aos padrões do belo então vigentes. No esforço de afrontarem a artificialidade estudada do classicismo, os românticos viam no popular a materialização do simples e do ingênuo com a qual poderiam nutrir suas novas experiências artísticas.

É interessante observar, contudo, que o declínio do romantismo na segunda metade do século XIX não traria nenhuma alteração a este quadro. Ao contrário, todos os limites e distorções que desde cedo cercaram a idéia de "cultura popular" seriam levadas às últimas conseqüências pelos chama-

2 Utilizo aqui do brilhante texto de Peter Burke, intitulado "A descoberta do povo" - primeiro capítulo de Cultura Popular na Idade Moderna, Trad., São Paulo, Companhia das Letras, 1989, pp. 31-49.

3 Id., p. 32.

4 Id., p. 37. Renato Ortiz, no seu interessante opúsculo Cultura Popular: românticas e folcloristas, também chega a uma conciusâo semelhante; q. v., pp. 14-15. 
GOMES, PIínio Freire. Notas sobre a mediaçåo enıre o erudito e o popular.

dos folcloristas. Pois, com eles, a palavra "povo" passava a designar os setores da sociedade onde supostamente eram preservados os resquícios de um passado remoto, anterior à civilização. A tendência de caracterizar o proletariado como uma horda de seres incultos alcança o seu ápice, enquanto o campones começa a ser comparado (de forma cada vez menos elogiosa) ao homem primitivo ${ }^{5}$.

Além disso, os folcloristas acabariam aprofundando ainda mais o desinteresse pela dinâmica da cultura popular tomada na sua totalidade. Fiéis discípulos do positivismo, eles acreditavam que os fatos podiam valer por si, sem a necessidade de conectá-los ao conjunto das relações sociais nas quais eram engendrados ${ }^{6}$. Mesmo porque, se as tradiçōes populares constituíam como se presumia - uma amálgama de heranças dispersas que foram fundidas ao longo do tempo, qualquer tentativa de interpretar o seu significado presente seria algo inútil: bastava descrevê-las. Assim, embora rejeitassem os interesses puramente estetizantes dos românticos e se propusessem a percorrer o universo popular a partir de um enfoque mais científico, os folcloristas nunca deixaram de ser meros caçadores do pitoresco.

Esse processo de involução do conceito de cultura popular só começaria a ser revertido em pleno século XX, no cerne das reflexões sobre o papel político dos intelectuais desenvolvidas por Antonio Gramsci ${ }^{7}$. O seu ponto de partida era a hipótese de que, mesmo quando submetido ao mais embrutecedor dos trabalhos braçais, o homem continua sendo, acima de tudo, um ser pensante - afinal, "não se pode separar o homo faber do homo sapiens". Mas se esta idéia muito simples fôr vista sob um prisma sociológico, teremos de concluir que, para garantia de sua própria homogeneidade, cada grupo social "cria para si (...) uma ou mais camadas de intelectuais" ${ }^{8}$.

$\mathrm{E}$ se isto vale para a aristocracia do feudalismo, ou para o moderno empresariado industrial, o mesmo deve ser dito para qualquer extrato subalterno. Em outras palavras, a luminosa frase talhada cem anos antes pelos irmãos Grimm estava sendo revestida agora por um significado bem mais amplo: além de belas estórias, Gramsci nos faz perceber que o povo cria

5 ORTIZ, Renato, Op. cit., pp. 22-24.

6 Este e muilos outros aspectos epistemologicos dessa "ciência mediana" que era o folclorismo såo discuticlos no.mesmo trabalho de Renato Ortiz, ìs pp. 17-59.

7 Como se sabe, é muito difícil periodizar os textos gramscianos. Mas, segundo consta, este tema somente passou a ser abordado por ele depois da sua prisấ, em 1926. Cf. Tom Ottomore. Dicionário do Pensamento Marxista. Trad., 2". ed., Rio de Janeiro, 1988, pp. $165-168$. Civilizaçâo Brasileirn, 1979, pp. 7 e 3, respectivamente. 
cultura no sentido forte do termo - ou seja, cria uma concepção de mundo. Pela primeira vez ficava claro que as camadas populares não se contrapōem ao pensamento oficial apenas no terreno da fruição estética, pois suas incompatibilidades se estendem à esfera da experiência política e também da própria postura existencial.

Apesar disso, é inegável que Gramsci ainda mantem-se demasiadamente preso ao viés estabelecido pelos folcloristas. Senão vejamos: de acordo com ele, o saber produzido entre os oprimidos seria marcado por uma profunda falta de consistência interna,

pois o povo (...) não pode - por definição - ter concepç̃es elaboradas, sistemáticas e politicamente organizadas e centralizadas em seu (ainda que contraditório) desenvolvimento (...) se é que não se pode mesmo falar de um aglomerado indigesto de fragmentos de todas as concepçóes de mundo e da vida que se sucederam na história?.

Portanto, a interpretação do popular como uma espécie de museu vivo do passado permanece intacta. Aliás, ele chegaria até mesmo ao ponto de recuperar a decadente tese do difusionismo, segundo a qual os padróes culturais transmitidos pela elite tendem a ser absorvidos de forma mais ou menos desordenada pelo restante da socidedade.

O folclore, acreditava Gramsci, sempre esteve ligado à cultura da classe dominante e, a seu modo, extraiu dela motivos que se inseriram nele em combinações com as tradições precedentes. Outrossim, não há nada mais contraditório e fragmentário do que o folclore ${ }^{10}$.

Não estamos longe, porém, do momento no qual a cultura popular é finalmente compreendida em sua plenitude. Poucos anos após a morte de Gramsci, este passo decisivo seria dado por um ainda obscuro historiador da fó meu.

10 Id., p. 189. A propósito, é curioso observarmos que até na própria formulaçấo do conceito de "intelectual orgânico", Gramsci também se deixarin influenciar pela perspectiva difusionista. Há uma passagem na qual, apús afirmar que as exigências artísticas do povo sâo elementares e confusas, ele acusava a intelectualidade de sua época de náo ter "sabido elaborar um 'humanismo' moderno, capaz de se difundir alé as camadas mais loscas e incultas" (sic). Id, p. 108. 
literatura russo - Mikhail Bakhtin ${ }^{11}$. Ao estudar o contexto de Rabelais, ele verificou que até o século XVI a vida cotidiana do europeu era permeada por ritos carnavalescos de extrema complexidade. E, como fossem regidos pela mais absoluta irreverência, argumentou que seria impossível filiá-los à ideologia dos grupos dominantes. Para Bakhtin, tratar-se-iam, na verdade, de manifestações nitidamente populares, embora fincassem raízes na mais remota antiguidade: seu potencial utópico e insubmisso derivaria de um período anterior ao próprio surgimento das classes sociais. Nesse sentido, o povo também lhe sugere a imagem de um refúgio de tradiçöes obscurecidas pelo tempo; mas, ao contrário dos folcloristas, a principal preocupação dele é salientar a consciência que os alegres súditos de Momo tinham dos significados profundos dos seus atos. Aquelas celebrações cristalizariam uma riquíssima cosmologia, cujo conteúdo era necessariamente conhecido e reconhecido por todos.

Até aqui, como se vê, ainda existe algum parentesco com os postulados gramscianos - pois, a festa também é pensada em termos de "concepção de mundo". Uma diferença crucial, porém, precisa ser ressaltada: Bakhtin era categórico ao apontar a indissolúvel coesão da cultura popular. É certo que o espírito carnavalesco costumava assumir as mais variadas formas, colorindo com o seu brilho desde simples provérbios satíricos até extensas procissões de carros alegóricos e intrincadas pantomimas. Mas, de acordo com ele, ao invés de obrigar-nos a apreender o popular enquanto algo fragmentário, esta multiplicidade evidenciaria as infinitas combinações entre elementos retirados de um mesmo arcabouço temático - o "realismo grotesco". Era utilizando esta bizarra forma de linguagem que os foliões podiam visualizar e, ao mesmo tempo, estreitar os seus laços coletivos.

Assim, as manifestações culturais do povo começavam a revelar um perfil bem diverso daquele traçado por Gramsci. De massa amorfa, elas estavam passando a ser encaradas como um organismo dotado de vitalidade própria, onde existe sim lugar para comportamentos elaborados, sistemáticos e politicamente centralizados. Eis aqui o grande mérito de Bakhtin. Ao salientar estes sinais de uma inequívoca autonomia, ele imprimiu à noção de cultura popular o mesmo significado

11 Escrita em 1940, sua célebre tese sobre a Cultura Popular na Idade Média e no Renascimento teve a honra de ser devidamente recusada pelas academias soviéticas. Foi apenas em 1965 que houve suficiente disposição política para imprimi-la. Cf. Yara Frateschi Vieira. "Introduçấo" In: François Rabelais. Gargantua. Trad., São Paulo, Hucitec, 1986, p. 17. 
atualmente utilizado por nós. Contudo, é preciso notar que na base dessa reformulação conceitual insinua-se a sombra de um certo apriorismo: boa parte dos raciocínios de Bakhtin acabam sobrepujando em demasia o propósito de circunscrever o território do popular para, sempre que possível, confrontá-lo ao mundo erudito. Ele alegava, por exemplo, que todos os ritos e espetáculos organizados à maneira cômica apresentavain uma diferença notável, uma diferença de princípio poderíamos dizer, em relação às formas do culto e às cerimônias oficiais (...) Ofereciam uma visảo do mundo, do homem e das relações humanas totalmente diferente, deliberadamente não-oficial, exterior à Igreja e ao Estado; pareciam ter construído, ao lado do mundo oficial, um segundo mundo e uma segunda vida ${ }^{12}$.

Sem dúvida, tal atitude se justifica com facilidade quando nos reportamos ao contexto no qual Bakhtin escrevera. As conotações depreciativas incorporadas ao termo "cultura popular" só poderiam ser eliminadas com a descoberta de um complexo de valores rigorosamente separados da ótica dominante. Mas, como se verá a seguir, este modelo cultural polarizado tem muito pouca ligação com a realidade porque negligencia algo fundamental: a economia de trocas e influências mútuas que tendem a atravessar todas as fronteiras do binômio elite-povo. De fato, o conceito altamente dialógico de "circularidade" não foi, ao contrário do que se costuma dizer. cunhado por Bakhtin ${ }^{13}$.

É óbvio que sua análise indica inúmeras vezes a existência deste processo. Afinal, ele nunca chega a supor que os ritos carnavalescos fossem algo estritamente popular. Pelo contrário: embora Bakhtin fizesse absoluta

12 Id., pp. 4-5 (grifado no original). A preocupaçăo de registrar a fissura entre os dois extremos da escala social é, com certeza, uma das principais tônicas do seu trabalho. Em outra passagem. Bakhtin afirma que "a riquíssima cultura popular do riso na Ichale Média viveu e desenvolveu-se fora da esfera oficial da ideologia e da literatura elevada" (p. 62). E, mais adiante, comenta o direito de impunidade reservado \̀ praça pública, assinalando que este espaço "formava um mundo único e coeso onde todas as 'tomadas de palavra' (...) possuíam alguma coisit em comum, pois estavam impregnaclas do mesmo ambiente de liberdade, franqueza e familiarichaden (p. 132).

13 A palavra "circularidade" só seria aplicada com esse significado por C'arlo t:inzburg. E talvez resida ấ a origem de toda confusâo, pois ele deu a entender que a retirou da obra de Bakhtin. Q.v. $O$ Queijo e os Vermes. Trad., Sẫo Paulo, Cia. clas Letras, 1987, pp. 13, 21 e, especialmente, 26. Acrescento, porén, a ressalva de que não li Bakhtin no original, nem cheguei ainda a conferir a versão francesa que foi utilizack por Ginzburg. 
GOMES, Plínio Freire. Notas sobre a mediação entre o erudito e o popular.

questão de frisar o caráter "não-oficial" de tais celebrações, sempre deixou bem claro que a euforia festiva envolvia a todos - do reles mendigo ao mais eminente dos burocratas. Não podemos nos esquecer também de que, focalizando o caso de Rabelais, o objetivo central do seu trabalho era mostrar em qual medida o "realismo grotesco" acabaria por fecundar boa parte da literatura renascentista.

Além disso, o tema do diálogo entre níveis de locução antagônicos apareceria com enorme ênfase na sua já mencionada obra acerca da poética de Dostoiévski. Foi ali que Bakhtin concebeu a categoria de dialogicidade para representar a trama formada pela interação de consciências eqüipotentes e plenivalentes - eixo em torno do qual gira o romance polifônico ${ }^{14}$.

De qualquer modo, seu esforço em captar a auto-suficiência das manifestaçóes populares deixou pouco espaço para que elas fossem interpretadas dialogicamente. $\mathrm{Na}$ tentativa de oferecer novas bases a uma desgastada conceitualização do "popular", Bakhtin precisou recorrer à idéia de que o povo age de forma autônoma em relação ao mundo cultural da elite. Mas quando se olha retrospectivamente, percebe-se o quanto esta idéia básica já estava presente em todos os autores que o precederam. Nesse sentido, a evolução histórica do conceito de "cultura popular" lembra uma figura em espiral, pois está sempre se fechando sobre si mesma. Ou, dito de outro modo, Bakhtin e, por extensão, nós (que somos seus sucessores diretos) ainda mantemos afinidades profundas com Gramsci, com os folcloristas e com os românticos - numa seqüência que nos leva até o século XVIII de Herder simplesmente porque a estrutura essencial daquele conceito nunca foi alterada: o "popular" continua a ser visto como a contraface simétrica e invertida do "erudito".

\section{Em busca dos intermediários culturais}

Hoje, no entanto, é preciso reconhecer que estamos vivendo numa situação muito diversa. Os compromissos que formaram a base da interpretação bakhtiniana não coincidem mais com os nossos. E a necessidade de uma mudança de perspectiva já começa a se fazer sentir. Segundo Peter Burke, por exemplo, 
a fronteira entre as várias culturas do povo e as culturas das elites (e estas eram tão variadas quanto aquelas) é vaga e por isso a atenção dos estudiosos do assunto deveria concentrarse na interação e não na divisão entre elas ${ }^{15}$.

Portanto, se a abordagem da cultura popular tem o mérito de romper o mutismo da documentação a respeito dos grupos sociais marginalizados, é preciso assinalar que ela igualmente implica no aparecimento de novas dificuldades. Michel Vovelle notou is to com muita agudeza ao alertar para o perigo de que estejamos reduzindo o passado a um dualismo sumário e bastante grosseiro ${ }^{10}$. Ofícios como o dos atores ambulantes, ou dos lojistas de pequenos vilarejos, ou ainda dos mercenários e dos bandoleiros de estrada - cada um dos quais criando seus próprios modelos de conduta e de honra revelam que a oposição entre erudito e popular está muito longe de corresponder à complexidade de qualquer tecido social.

Porém, tal lacuna não está prejudicando apenas os estudos dedicados à convivência (e ao conflito) entre camadas culturalmente diferenciadas. $\mathrm{O}$ mesmo deve ser dito para aquela historiografia interessada em resgatar os traços mentais de natureza supraclassista. Afinal, se São Luis e o camponês de seus domínios possuiam algo em comum é de supor-se que entre eles havia uma vasta teia de canais por onde certas mensagens eram transmitidas e outras sintetizadas. E quem reconheceu a importância deste aspecto foi ninguém menos do que o próprio Jacques Le Goff no seu famoso ensaio "As mentalidades: uma história ambígua". De acordo com ele,

embora emprestadas a tradições muito antigas, essas mentalidades não se explicam nem pelas trevas da noite dos tempos, nem pelos mistérios do psiquismo coletivo. Encontram-se sua gênese e sua difusão a partir de centros de elaboração de meios criadores e vulgarizadores, de grupos e de profissóes intermediárias ${ }^{17}$.

Mas falemos de exemplos concretos. Em sua análise sobre a literatura de folhetim divulgada nas praças públicas, Burke constata que, durante o

15 BURKE, Peter. Op. cit., pp. 20-21.

16 Aqui - e também nas próximas referências a Vovelle - estarei me utilizando do seu ensaio "Os intermediários culturais" In: Ideologias e Mentalidades. Trad., São Paulo, Brasiliense, 1988, pp. 207-224.

17 LE GOFF, Jacques. "As Mentalidades: uma história ambígua." In: J. Le Goff e Pierre Nora (orgs.). História: Novos Objetos. Trad., Rio de Janeiro, Livr. Francisco Alves Ed., 1976, p.77. 
GOMES, Plínio Freire. Notas sobre a mediaģio entre o erudito e o popular.

período moderno, os ideais da aristocracia cavaleiresca ligados à coragem, à eficácia militar e à lealdade, receberam por parte da plebe uma acolhida extremamente favorável. Sob as vestes do cavaleiro, o nobre converteu-se num grande herói popular ${ }^{18}$.

Porém, Georges Duby apresenta-nos um fato ainda mais curioso: estes ideais não foram, como poderia parecer à primeira vista, estabelecidos pelos representantes da elite feudal. Diferentemente da noção de nobilitas - onde o brio está associado a uma origem ilustre -, a noção de milites que o identificava às armas - só existia entre os membros da baixa nobreza. A palavra militare não significava unicamente "lutar", mas também "servir". Será apenas a partir do século XII que duques e príncipes procurarăo forjar para si uma imagem guerreira ${ }^{19}$.

E com o absolutismo este gosto sofreria um novo impulso - basta lembrar que os grandes monarcas jamais dispensavam a espada ao posarem para seus retratistas. Carlos $\mathrm{V}$ chegaria mesmo a ser representado sobre um cavalo, de lança à mão e envergando uma lustrosa armadura, como se ainda combatesse aos exércitos mouros ${ }^{20}$. No entanto, há inúmeros exemplares semelhantes a este: além dos retratos eqüestres, que fizeram a delícia dos Felipes de Espanha e de seus duques, eu citaria os interessantíssimos retratos de Luís XIII, XIV e XV, nos quais a armadura sempre deixa bem à mostra um delicado lenço de rendas preso ao pescoço real. Afinal, os mimos da etiqueta náo teriam porque contrastar com o rigor de um traje marcial que já é puro adorno.

Em síntese, estamos diante de um caso de permanência mental típico da longa duração. Porquanto estes valores além de sobreviverem à estrutura sócio-económica na qual foram concebidos, eram partilhados coletivamente: ao manter-se vivo nas baladas populares, bem como nos salóes palacianos, a figura do nobre guerreiro pertenceu à esfera impessoal que embebia a sensibilidade de todos. Mas, em compensação, não deixa de ser verdadeiro o fato de que cada indivíduo tenderia a apropriar-se deste personagem segundo os parâmetros colocados pela sua própria classe social. Se para os reis o desejo de se associarem à imagem dos cruzados seria a forma mais conveniente de assegurar uma legitimidade recém-conquistada, para os camponeses ou pequenos artesãos o mesmo herói corporificava o sonho da independéncia frente aos estreitos liames da tradição e da pobreza. E, sendo assim, também

18 BURKE, P. Op. cit., pp. 181-183.

19 DUBY, Georges. The Diffusion of Cultural Patterns in Feudal Society Past and Present, Oxford, $n^{\circ} .39$, April, 1968 , pp. 7-8.

20 Refiro-me à teln de Ticiano Vecellio, intitulada "Carlos V na batalha de Mühlberg" (1548). 
R. Histórıa, São Paulo, n. 125-126, p. 65-80, ago-dez/91 a jan-jul/92.

estamos trabalhando com um caso de circularidade cultural; onde estratos bem delineados - e, por suposto, antagônicos - assumem formas de pensamento que visivelmente destoavam de sua realidade mais imediata.

Ora, seja no primeiro enfoque, seja no segundo, somos obrigados a nos voltar para aquela nebulosa de sujeitos que flutuavam entre a base e o topo da sociedade. Baronetes, menestréis, padres, criadas, charlatães, aventureiros de toda ordem - sem considerá-los seria impossível compreender não só a persistência, como também o nascimento desta nostálgica admiração pelo galante mundo dos cavaleiros.

Posto isso, passemos a discutir algo menos distante de nós: o Brasilcolônia. Qual seria a importância dos intermediários numa sociedade caracterizada pelo uso do trabalho compulsório em larga escala? Se aqui o convencimento equivalia, na grande maioria das vezes, à violência pura e simples, que peso poderiam ter os "centros de elaboração" mencionados por Le Goff? A primeira parte de uma possível resposta insinua-se num dado já bastante conhecido. A oposição senhor-escravo era o eixo fundamental do processo produtivo, mas não o único. Basta lembrar que as chamadas "atividades intersticiais" tambem engajavam alguns homens livres de baixa renda; e, seguramente, maneiras bem particulares de encarar o mundo devem ter despontado ali.

No entanto, esta sociedade foi muito mais complexa do que estávamos acostumados a imaginar. Embora o elemento servil indique a presença de um princípio hierárquico de extrema rigidez, no plano da cultura as coisas se passavam de modo totalmente diverso. As pesquisas mais recentes vêm mostrando que crenças, valores e comportamentos tendiam a superar as barreiras erigidas pela riqueza e pelo poder. É óbvio que o discurso dos grandes proprietários encontrava eco na rede de agregados, dependentes e capatazes, repercutindo ainda entre os escravos mais submissos ou mais suscetíveis a certos privilégios. Por outro lado, sabemos hoje que parte do imaginário elaborado nas capoeiras e senzalas também se infiltrava nos grupos dominantes; e o caso da magia, devassado por Laura de Mello e Souza, é uma notável prova disso ${ }^{21}$. As dissonâncias não surgiam apenas nas margens, ou nos interstícios do sistema, e sim no seu próprio centro.

Mas se tal raciocínio é correto, devemos também reconhecer as suas conseqüências. Acima de tudo, ele nos obriga a reavaliar alguns conceitos

21 SOUZA, Laura de Mello e. O Diabo e a Terra de Santa Cruz. Sấo Paulo, Companhia das Letras, 1986, sobretudo, o capítulo "Deflagraçâo de conflitos" - no qual a generalizada propensão às práticas mágicas aparece como um resultado direto das tensöes da sociedade escravista; pp. 194-226. 
GOMES, Plínio Freire. Notas sobre a mediaçâo entre o erudito e o popular.

introduzidos pela historiografia européia - a quem, aliás, geralmente caímos no erro de reproduzir sem tomar os devidos cuidados. De fato, a distinção entre "cultura popular" e "cultura erudita" torna-se ainda mais artificial quando tentamos compreender a colônia. O multifacetado perfil étnico que caracterizou a possessão portuguesa na América dificultava em muito o estabelecimento de parâmetros mentais isolados e auto-suficientes.

Sem dúvida, não estou pretendendo refutar in totum o uso destes conceitos. Afinal, seria absurdo imaginar uma camada dominante desprovida de sustentação ideológica. Ou, inversamente, falar em setores subalternos que fossem incapazes de articular um pensamento alternativo. Porém, como nos mostra Luis Felipe de Alencastro na sua obra $O$ Trato dos Vivos, a ser publicada em breve, a metrópole implantou a colonização sem ter por base nenhum tipo de modelo pré-concebido ${ }^{22}$. Infelizmente sou obrigado a omitir muitos detalhes; mas, de certa forma, o texto de Alencastro nos leva a inferir algo bastante sugestivo: todos os papéis sociais que os colonos deveriam representar foram gestados a partir de nada - ou melhor, de quase nada, dado que subjacente a eles havia apenas o "sentido" posto pelas relações mercantis.

Acrescente-se ainda que até as convicções mais sólidas sofriam um forte impacto ao desembarcarem nestes trópicos. Os mesmos jesuítas que no Velho Mundo viam os festejos populares com extrema intolerância, foram contagiados aqui (ao menos no início) por uma espécie de aculturação às avessas. Com a finalidade de atraírem a indiaria, não hesitaram em se misturar alegremente aos seus costumes ${ }^{23}$.

Todavia, como indiquei há pouco, aquela ordem econômica obviamente acabaria encontrando um arcabouço de valores dentro do qual pôde movimentar-se sem maiores constrangimentos. E a célebre frase de André Antonil - "o ser senhor de engenho é título a que muitos aspiram, porque traz consigo o ser servido, obedecido e respeitado de muitos" ${ }^{24}$-, revela uma situação onde os papéis sociais não só já se encontram delineados, como também conseguem catalisar as ambições de numerosas parcelas da população.

Faço aqui uma leitura livre das interessantes colocaçōes feitas por Alencastro em " $\mathrm{O}$ aprendizado da colonização", primeiro capitulo de Le Commerce de Vivants: traite d'esclaves et "Pax Lusitana" dans l'Atlantique sud, tese de doutorado defendida na Universidade de Paris X, entre 1985 e 1986. Devo esta indicação ao meu colega Pedro Puntoni.

23 Sobre a intolerância dos inacianos europeus, q.v. P. Burke. $O$ p. cit., p. 245; e sobre a mistura com os costumes nativos, v. o texto de Mary Del Priore "O papel branco, a infancia e os jesurtas na colônia" In: Idem (org.) História da Criança no Brasil. São Paulo, Contexto, 1991, pp. 10-27.

24 ANTONIL, André João. Cultura e Opulência do Brasil. $3^{\text {a }}$. edição, Belo Horizonte, ItatiaiaEdusp, 1982, p. 75. 
Resumindo, entre a época tumultuária da colônia ainda emergente e o quadro descrito acima, teria transcorrido um longo e sinuoso processo de aprendizagem. A posição de cada potentado, bem como a dos trabalhadores colocados a seu serviço, variava incessantemente ao sabor dos motins, das instabilidades no mercado internacional, ou das invasões estrangeiras. E a tudo isto somavam-se as influências propagadas por um irriquieto meio urbano em pleno crescimento ${ }^{25}$. Neste ínterim, era inevitável que os elementos mais heteróclitos terminassem por ser conjugados: o "viver em colónias" - como dizia Vilhena - foi, se me permitem a imagem duvidosa, um prenúncio da nossa "geléia geral".

Portanto, ao contrário do que parecia inicialmente, a preocupação de Burke no sentido de acentuar a pluralidade do universo mental das elites e do povo, adquire na colônia um significado bem mais contundente. E, é claro, o mesmo pode ser dito com respeito ao problema do intercambio cultural: pois, enquanto na Europa as mediações restringiam-se a determinados ofícios, no Brasil elas eram, em maior ou menor medida, uma experiência vivenciada por todos.

\section{Conclusấo}

Para concluir, é interessante fazermos uma breve reflexão sobre as principais questões metodológicas suscitadas por este tema. Em poucas palavras, quais são as vantagens e desvantagens que o estudo dos intermediários poderá nos proporcionar? Ou melhor: qual é, afinal de contas, nosso verdadeiro objetivo quando nos lançamos a sua procura?

Antes de mais nada, eu me apressaria em responder qual objetivo nós nunca deveremos perseguir. Conforme adverte Vovelle, os intermediários culturais não representam o terceiro termo que, em boa hora, iria nos livrar da visão simplificadora baseada em duas camadas - como se este novo esquematismo pudesse superar os defeitos do anterior. Na realidade, estamos lidando com um fenômeno essencialmente difuso. E para abarcá-lo será preciso renunciar, desde logo, à esperança de descobrir padrōes constantes, ou elementos reiterativos. Como sabemos, as pesquisas em torno do erudito

Caio Prado Júnior foi o primeiro a mostrar como a expansão das cidades - sobretudo a partir de meados do século XVII - acabou transformando a socieclade colonial num organismo bem mais complexo, cujos interesses paulatinamente começariam a diferenciar-se em relação aos da me. trópole. Evolução Política do Brasil. 16". ediçāo, Ș̃o Paulo, Brasiliense, 1987, pp. 33-44. 
GOMBS, Plinio Freire. Notas sobre a mediaçåo entre o erudito e o popular.

e do popular costumam dar margem a sínteses bastante audaciosas; porém, no presente caso, o que nos cabe fazer é um minucioso trabalho de lupa. Até porque, a documentaçăo raras vezes permite ir além do nível estritamente individual.

Não obstante tudo isto, creio que os intermediários têm muito a nos oferecer. Por habitarem na encruzilhada entre as várias lógicas que fundamentavam as atitudes de seus contemporâneos, eles encarnam como ninguém aquilo que chamamos de "testemunhas privilegiadas".

Pois é necessário termos em mente que essa origem ambígua devia ser um sério empecilho para a consolidação de qualquer tipo de identidade pessoal. E, com certeza, boa parte deles preferia dissimular as semelhanças que os aproximavam aos grupos populares, transformando-se em ferozes defensores dos ideais encastelados no centro do poder. Um exemplar bem característico desta tendência foram os capatazes das primeiras fábricas da era industrial. Ou, para o Brasil colonial, os capitães-do-mato, nos quais se concentrou de forma mais cristalina e acabada toda crueza do regime escravista. Já outros decidiram trilhar o caminho inverso, assumindo posturas marcadas por uma rebeldia profundamente avassaladora. Foi este o caso da sans-culloterie, mas também dos conjurados baianos de 1798: o movimento político de maior radicalidade da colónia germinou justamente entre pequenos artesáos, lavradores de cana falidos e militares de baixa patente.

No entanto, certos intermediários souberam se nutrir avidamente nos dois extremos da hierarquia social e, por conta própria, assumiram a tarefa de dar coerência à multiplicidade de valores que vigoravam em sua época. Lembremos, por exemplo, de Rétif de la Bretonne - 0 admirável "filósofo do esgoto" que, segundo Rouanet, conseguiu aglutinar em si cada uma das facetas da revolução francesa. Da plebe urbana aos aristocratas, da burguesia ao campesinato: todas as categorias sociais em conflito tiveram nele um ardoroso defensor dos seus interesses; pois, conforme dizia o próprio Rétif, Que alegria poder abraçar todas as condiçöes! Por minhas roupas eu me elevo ao nível dos grandes, e amanhă desço e me confundo com os mais baixos dos homens. Essas mudanças subitas e variadas dilatam a minha existência: $\mathrm{eu}$ sou de todas as classes ${ }^{26}$.

Por outro lado, esta posição estratégica que eles ocupavam também os transforma num ponto nodal para 0 avanço das discussões movidas pelas

26 ROUANET, Sérgio Paulo. Apud. O Espectador Noturno. Şo Paulo, Companhia das Letrns, 1988, Pp. 45-46 (grifado no original). 
principais linhagens da atual historiografia. Como procurei demonstrar aqui, a figura intermediária nos ajuda a compreender que as mentalidades não constituem um ente misterioso e abstrato, mas sim o produto de fluxos e refluxos no contato direto entre os homens. Além disso, este personagem híbrido nos indica que a herança bakhtiniana ainda está inacabada. E que poderemos aprimorá-la através de uma perspectiva capaz de perceber, nas fendas da muralha entre o erudito e o popular, o ruído de incontáveis vozes a se fundirem e a se duelarem. Talvez venhamos, assim, a conhecer melhor os meandros desse dialógico campo de batalha que chamamos de cultura.

São Paulo, dezembro de 1991.

\section{BIBLIOGRAFIA:}

ALENCASTRO, Luis Felipe de. "O Aprenclizado da Colonizaçăo". Primeiro capítulo de Le Commerce de Vivants: traite d' esclaves et "Pax Lusitana" dans 1' Atlantique sud. Tese de doutorado defendida na Universidade de Paris X, entre 1985 e 1986.

ANTONIL, André João. Cultura e Opulência no Brasil. $3^{\text {a }}$. edição, Belo Horizonte, Itatiaia-Edusp, 1982.

BAKHTIN, Mikhail. Cultura Popular na Idade Média e no Renascimento - O Contexto de François Rabelais. Trad., São Paulo, Hucitec, 1987.

Problemas da Poética de Dostoiévski. Trad., Rio de Janeiro, Forense Universitária, 1981.

BURKE, Peter. A Cultura Popular na Idade Moderna - Europa, 1500-1800. Trad., São Paulo, Companhia das Letras, 1989.

DEL PRIORE, Mary. "O papel branco, a infância e os jesuítas na colônia" In: IDEM (org.). História da Criança no Brasil. São Paulo, Contexto, 1991, pp. 10-27.

DUBY, Georges. "The Diffusion of Cultural Patterns in Feudal Society" In: Past and Present, Oxford, $\mathrm{n}^{\circ} .39$, April, 1968, pp. 3-10.

GINZBURG, Carlo. O Queijo e os Vermes - o cotidiano e as idéias de um moleiro perseguido pela Inquisição. Trad., São Paulo, Cia. das Letras, 1987.

GRAMSCI, Antonio. Literatura e Vida Nacional. Trad., Rio de Janeiro, Civilização Brasileira, 1986.

Os Intelectuais e a Organização da Cultura. Trad., $3^{\mathrm{a}}$. ed., Rio de Janeiro, Civilização Brasileira, 1979.

LE GOFF, Jacques. "As Mentalidades: uma história ambígua" In: LE GOFF, J. e NORA, P. (orgs.) História: Novos Objetos. Trad., Rio de Janeiro, Livraria Francisco Alves Ed., 1976, pp. 68-83.

ORTIZ, Renato. Cultura Popular: romanticos e folcloristas. São Paulo, Programa de Estudos Pós-Graduados da PUC, 1985.

OTTOMORE, Tom. Dicionário do Pensamento Marxista. Trad., $2^{\text {a }}$. ed., Rio de Janeiro, 1988. 
GOMES, Plínio Freire. Notas sobre a mediaçáo entre o erudito e o popular.

PRADO JUNIOR, Caio. Evolução Política do Brasil - Colônia e Império. $16^{\text {a }}$. ediçăo, Săo Paulo, Brasiliense, 1987.

ROUANET, Sérgio Paulo. O Espectador Noturno - a revolução francesa através de Rétif de la Bretonne. Sáo Paulo, Cia. das Letras, 1988.

SOUZA, Laura de Mello. O Diabo e a Terra de Santa Cruz - Feitiçaria e religiosidade popular no Brasil Colonial. Sáo Paulo, Companhia das Letras, 1986.

VIEIRA, Yara Frateschi. "Introduçăo" In: RABELAIS, François. Gargantua. Trad., Săo Paulo, Hucitec, 1986, pp. 11-32.

VOVELLE, Michel. Ideologias e Mentalidades. Trad., Săo Paulo, Brasiliense, 1988.

ABSTRACT: Through the pioneer reflections of Gramsci and Bakhtin, one realized that the subordinate layers were also able to build their own conception of the world. But the iden of "popular

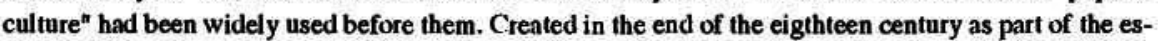
thetics proposals of romanticism, it helped found a dicotomic perception of the society that only now has been questioned. Today the importance of the individuals who acted as mediators between "erudite" and "popular" becomes clearer, establishing points of contact or reinforcing their zones of disagreement.

KEY-WORDS: Popular Culture, $18^{\text {th }}$ century, Romanticism, Literature and History, World view (Global view) 